фиксировать проведенные с несовершеннолетними и их семьями, а также надзорными гражданами социально-педагогические реабилитационные мероприятия, а также фиксировать наличие или отсутствие положительной динамики. Это будет способствовать выявлению наиболее и наименее результативных социально-педагогических реабилитационных мероприятий.

1. Федеральный закон «Об административном надзоре за лицами, освобожденными из мест лишения свободы» № 64-ФЗ от 06 апреля 2011 г. (ред. от 29.07.2017). - URL: http://base.garant.ru/12184517/ (дата обращения: 03.09.2021). - Текст : электронный.

2. Федеральный закон «Об основах системы профилактики безнадзорности и правонарушений несовершеннолетних» № 120-ФЗ от 24 июня 1999 г. - URL: https://base.garant.ru/12116087/ (дата обращения: 08.09.2021). - Текст : электронный.

3. Федеральный закон «Об основах системы профилактики правонарушений в Российской Федерации» № $182-$ Ф3 от 23 июня 2016 г. . - URL: https://base.garant.ru/71428030/ (дата обращения: 08.09.2021). - Текст : электронный.

4. Приказ МВД России от 15 октября 2013 г. № 845 «Об утверждении Инструкции по организации деятельности подразделений по делам несовершеннолетних органов внутренних дел Российской Федерации». - URL: http://base.garant.ru/70585810/ (дата обращения: 02.09.2021). - Текст : электронный.

5. Приказ МВД РФ от 29 марта 2019 г. № 205 «О несении службы участковым уполномоченным полиции на обслуживаемом участке и организации этой деятельности». - URL: https:/www.garant.ru/products/ipo/prime/doc/72188134/ (дата обращения: 02.10.2021). - Текст : электронный.

6. П Приказ МВД РФ от 8 июля 2011 г. № 818 «О Порядке осуществления административного надзора за лицами, освобожденными из мест лишения свободы». - URL: http://www.garant.ru/products/ipo/prime/doc/12089141/ (дата обращения: 02.10.2021). - Текст : электронный.

7. Гриценко, Л. И. А.С. Макаренко: педагогика трудного детства / Л. И. Гриценко. - Волгоград, 2003. - 241 с. Текст : непосредственный.

8. Днепров, С. А. Генезис представлений отечественных педагогов о сущности социально-педагогической реабилитации педагогически запущенных обучающихся / С. А. Днепров, С. О. Хилюк. - Текст : непосредственный // Муниципальное образование: инновации и эксперимент. - 2020. - № 3 (72). - С. 40-50.

\title{
Шульгин А.А. \\ Сущность административно-правовых методов деятельности полиции в контексте качества достижения правоохранительной цели
}

Краснодарский университет МВД России (Россия, Краснодар)

doi: 10.18411/trnio-11-2021-271

\section{Аннотация}

Целью статьи является исследование имеющихся доктринальных положений относительно определения сущности административно-правовых методов деятельности полиции с целью их дальнейшего анализа. В данной статье аргументирована важность исследуемых методов через призму обязанностей полиции по обеспечению охраны прав и свобод человека, противодействию преступности, поддержания публичной безопасности и порядка; правильное применение соответствующих правовых инструментов играет особое значение в построении отношений полиции с социумом, способствует развитию прочного взаимодействия последних и является залогом развития стабильного, развитого и правового государства.

Ключевые слова: административно-правовые методы, методы деятельности полиции, классификация, убеждение, принуждение, поощрение.

\section{Abstract}

The purpose of the article is to study the existing doctrinal provisions regarding the definition of the essence of administrative and legal methods of police activity in order to analyze 
them further. This article substantiates the importance of the investigated methods through the prism of police duties to ensure the protection of human rights and freedoms, to combat crime, to maintain public safety and order; the correct application of the relevant legal instruments is of particular importance in building relations between the police and society, contributes to the development of lasting interaction of the latter and is the key to the development of a stable, developed and legal state.

Keywords: administrative and legal methods, methods of police activity, classification, persuasion, coercion, encouragement.

Постановка проблемы. Приоритет прав и свобод человека в сегодняшних условиях требует от полиции использования качественно новых методов деятельности, которые должны соответствовать современным условиям развития государства и в своей последовательности и совокупности положительно влиять на эффективное выполнение полицией возложенных на неё задач.

В своей деятельности, для достижения поставленных целей, полиция применяет соответствующие административно-правовые методы, из которых основными являются убеждение и принуждение. Целью данной статьи является исследование существующих доктринальных положений относительно определения сущности административно-правовых методов и методов деятельности полиции с целью формирования собственного их определения.

Изложение основного материала. Права и свободы человека и их гарантии определяют содержание и направленность деятельности государства. Государство отвечает перед человеком за свою деятельность. Утверждение и обеспечение прав и свобод человека является главной обязанностью государства . В связи с этим, для обеспечения выполнения возложенных на государство обязанностей, создана и функционирует система правоохранительных органов, среди которых, полиция занимает ведущее место. А.В. Куракин обращает внимание на необходимость детального изучения и исследования вопросов административно-правовых методов деятельности правоохранительных органов страны, поскольку не последняя роль в их негативной деятельности принадлежит неуместному использованию имеющегося спектра административно-правовых методов, по результатам которых дается общая оценка государству. Характер и содержание задач, которые выполняют правоохранительные органы, требуют применения в их деятельности специфических методов, ведь, то, каким образом правоохранительные органы будут выполнять поставленные государством задачи, определяет степень и качество достижения правоохранительной цели.

Учитывая изложенное, считаем исследование административно-правовых методов деятельности полиции актуальной задачей, требующей особого внимания. Вместе с этим следует отметить, что для полного и всестороннего проведения исследования обозначенного вопроса необходимо ознакомиться с понятиями «методы административного права» и «административно-правовые методы», что позволит определить их понятие, признаки и предоставить классификацию.

В большинстве учебников по административному праву, в которых, как можно утверждать, заложены только основные теории и положения административного права, «метод административного права» рассматривается как «метод административно-правового регулирования», или «административно-правовой метод». Что касается сущности указанных дефиниций, то С.Н. Шаклеин понятие «административно-правовой метод» отождествляет с понятием «метод административного права» и отмечает, что это - совокупность правовых средств и способов (приемов), применяемых органами управления для обеспечения регулирующего влияния норм административного права на общественные отношения.

Другой ученый Л.Р. Геккиева, придерживается позиции, что «административноправовой метод» или «метод правового регулирования» должен рассматриваться как инструмент государства, где организуется и обеспечивается деятельность субъектов в 
соответствии с нормами права, устанавливается связь между правами и обязанностями последних, который придает общественным отношениям соответствующий порядок.

Группа авторов под методом административного права понимают совокупность приемов (способов, средств) воздействия, с помощью которых устанавливается юридически властное и юридически подвластное положение субъектов в правоотношениях.

Метод административного права как правовую категорию следует рассматривать в широком и узком смыслах. Так, в первом, широком, смысле - это специфическая совокупность зафиксированных в административно-правовых нормах способов и приемов воздействия на те общественные отношения, которые образуют предмет административного права, сбалансированное применение которых дает возможность создать надлежащие и достаточные условия для обеспечения реализации и защиты прав и свобод личности в публичной сфере. Что касается узкого понимания, то метод административного права-это конкретная совокупность инструментов регулировочного влияния на отдельную разновидность административных правоотношений.

Анализ предложенных определений, предоставленных ведущими специалистамиадминистративистами, указывает на их многообразие, несмотря на разное словесное выражение, понятие методов административного права существенно не отличаются, теоретики предоставляют почти идентичные его трактовки.

Рассматривая административно-правовые методы деятельности полиции, справедливо утверждать, что в административных методах деятельности правоохранительных органов наиболее ярко выражается исполнительно-распорядительная природа административной деятельности, а использование административных методов позволяет субъекту этой деятельности прямо влиять на объект деятельности, добиваться необходимого подчинения.

Так, под административно-правовыми методами деятельности полиции понимаются предусмотренные административно-правовыми нормами средства, приемы и способы, с помощью которых полиция осуществляет влияние на общественные отношения с целью реализации своих правоохранительных задач и функций. Это целенаправленный способ поведения, набор действий и средств, которые повторяются и ведут к решению задач по обеспечению публичной безопасности и порядка, охраны прав и свобод человека, а также интересов общества и государства; противодействию преступности; оказанию в пределах, определенных законом, услуг по помощи лицам, которые из личных, экономических, социальных причин или вследствие чрезвычайных ситуаций нуждаются в такой помощи.

Проанализировав приведенные научные определения, приходим к выводу, что понятие «метод административного права» и «административно-правовые методы деятельности полиции» можно соотнести как общий и отраслевой методы. То есть для достижения цели, а именно выполнения возложенных законом задач, полиция использует соответствующие методы, которые урегулированы нормами административного права.

Поскольку выполнение административно-правовых методов гарантируется государством, и они являются обязательными для исполнения теми субъектами, которым адресованы, административно-правовые методы деятельности полиции является составной частью административно-правовых методов, которые имеют свою специфику, средства, способы и инструменты для выполнения возложенных задач.

Таким образом, опираясь на приведенные определения теоретиков права, определив место административно-правовых методов деятельности полиции в системе методов административного права, можно предложить их определения как предусмотренные законом средства, способы и приемы практического осуществления организационного влияния полицейских, в пределах компетенции, на конкретных субъектов, объекты или общественные отношения для выполнения определенных задач и достижения желаемой цели.

Административно-правовые методы соответствуют определенным требованиям, а именно: обладают способностью формировать и обеспечивать реализацию правозащитных 
воздействий; должны быть различными и приспособленными к широкому использованию; должны быть реальными и гибкими.

Учитывая, что нас интересуют именно административно-правовые методы в деятельности полиции, целесообразно определить классификацию этих методов сквозь призму приоритетных направлений ее деятельности. Так, универсальными методами деятельности полиции, которые составляют систему средств влияния правоохранительных органов на сознание и поведение людей и являются необходимым условием их нормального функционирования, являются убеждение и принуждение. Сочетание этих двух методов составляет универсальный принцип социального управления, который распространяется через систему методов стимулирования, среди которых - административные, социальнопсихологические и экономические.

Метод убеждения в деятельности полиции используется при выполнении задач в пределах определенной компетенции. Поэтому, выполняя решение или применяя правовые нормы в своей деятельности, работник полиции должен убедиться, что субъект знает свои права и обязанности, а также имеет возможность добровольно выполнить требования действующего законодательства.

Таким образом, метод убеждения можно определить как систему мер воспитательного и поощрительного характера, направленное на формирование у объекта привычки добровольно, то есть через внутреннее признание, выполнять требования норм права. Ключевым признаком, выделяющим указанный метод, является его добровольный характер, а главной целью является формирование в сознании чувства убеждения в необходимости соблюдения установленных норм. С помощью мер убеждения стимулируется должное поведение участников административно-правовых отношений.

К самым распространенным формам его использования относят: осуществление систематической разъяснительной работы по административно-правовым актам; критика правонарушений; информирование населения о состоянии обеспечения правопорядка; поощрение граждан, участвующих в охране общественного порядка.

Применение только одного метода убеждения в деятельности полиции является недостаточным, поэтому с целью эффективного воздействия на правонарушителей, обеспечения законности и правопорядка, а также исполнение конкретными лицами установленных правил поведения сотрудники полиции уполномочены применять меры административного принуждения. Принуждение - это метод воздействия уполномоченного субъекта управления на сознание и поведение подчиненных объектов путем применения ограничений физического, материального, морального характера с целью предотвращения противоправных действий, применения наказания и воспитания правонарушителей.

Метод принуждения относится к наиболее жестким средствам воздействия, он является необходимым для охраны правопорядка, собственности, прав и интересов граждан и организаций, создания нормальных условий для существования. Учитывая современный этап реформирования правоохранительных органов, применение принуждения как метода деятельности полиции должно иметь исключительный характер и применяться лишь в том случае, когда все другие методы оказались неэффективными. Учитывая, что основными задачами полиции являются обеспечение публичной безопасности и порядка, охрана прав и свобод человека, интересов общества и государства, противодействие преступности, то применение полицейскими принуждения имеет свои особенности.

Принуждению присуща такая совокупность признаков: меры принуждения и порядок их применения устанавливаются законом и подзаконными нормативно-правовыми актами; принудительная мера применяется как средство обеспечения государственного управления системой; применяется только уполномоченными лицами; процессуальный порядок применения административного принуждения отличается достаточно высоким уровнем оперативности, что увеличивает его реализацию.

Метод государственного принуждения в деятельности правоохранительных органов может быть эффективным только при таких условиях, как: возникновение реальной угрозы 
совершения правонарушения, проявлений насилия, задержания лица правонарушителя, применение к нему мер административной ответственности, пресечения этого правонарушения, если применение методов убеждения не показало должного результата. Ученый отмечает, что этот метод включает меры административного прекращения, административного надзора и контроля, административно-правового запрета и административного регулирования. Принимая во внимание тенденции развития правоохранительных органов, целесообразным в деятельности полиции также является использование метода поощрения, который может являться самостоятельным методом административно-правовой деятельности.

В противоположность этому нам представляется, что выделять наряду с убеждением и принуждением метод поощрения вряд ли правильно, потому что он является составной частью убеждения. Несмотря на отсутствие единого подхода к пониманию этого метода, поощрение правомерного поведения - это достаточно распространенный метод административной деятельности, который эффективно используется в развитых странах мира, в частности США, Японии, Германии, Швеции и др.

Выводы. Подытоживая изложенное, необходимо сделать вывод, что важность значения административно-правовых методов в деятельности полиции состоит в том, что на неё, как на центральный орган исполнительной власти, возложена обязанность по обеспечению охраны прав и свобод человека, противодействию преступности, поддержания публичной безопасности и порядка. Поэтому их правильное применение играет особое значение в построении отношений полиции с общественностью, способствует развитию прочного взаимодействия последних и является залогом развития стабильного, развитого и правового государства.

$$
* * *
$$

1. Геккиева Л. Р. Деятельность полиции в обеспечения прав и свобод граждан //Научный электронный журнал Меридиан. -2020 . - №. 7. - С. 27-29

2. Кареева-Попелковская К. А. Полиция и меры административного пресечения //Право. Экономика. Безопасность. - 2017. - №. 1-2. - С. 65-66.

3. Куракин А. В. Вопросы административного принуждения //Административное и муниципальное право. 2021. - №. 2. - С. 10-24.

4. Самойлюк Р. Н., Давидов Д. С. Проблемы правового регулирования применения сотрудниками полиции физической силы как меры государственного принуждения //Вестник Московского университета МВД России. -2020 . - №. 2. - С. 18-21.

5. Шаклеин С. Н. Теоретико-правовые аспекты административной пенологии //Правоприменение. - 2021. - T. 5. - №. 1. - C. 202-211.

6. Юсупов Т. Р. Сущность методов воздействия на сознание и поведение лиц в процессе осуществления административной деятельности сотрудниками полиции //Актуальные проблемы государства и общества в области обеспечения прав и свобод человека и гражданина. - 2017. - №. 5. - С. 95-99.

7. Ямалитдинов А. А. Административно-предупредительные меры, применяемые полицией //Актуальные проблемы государства и общества в области обеспечения прав и свобод человека и гражданина. $-2019 .-$ №. 1. - C. 377-380.

\section{Ягармин Р.Г. \\ Гносеолого-методологическая функция юридических конструкций \\ Крф ФГБОУВО «Российский государственный университет правосудия» \\ (Россия, Симферополь)}

doi: 10.18411/trnio-11-2021-272

\section{Аннотация}

В статье рассмотрена гносеолого-методологическая функция юридических конструкций, посредством которой раскрывается ее суть и практическое значение. Выделено три уровня познания права. Проанализировано понятие юридической конструкции, ее суть и практическое значение. Продемонстрировано значение метода моделирования.

Ключевые слова: юридические конструкции, гносеолого-методологическая функция, метод моделирования, уровни познания права. 